\title{
X-linked lissencephaly with abnormal genitalia
}

INSERM

\section{Source}

INSERM. (1999). Orphanet: an online rare disease and orphan drug data base. $\underline{X-l i n k e d}$ lissencephaly with abnormal genitalia. ORPHA:452

X-linked lissencephaly with abnormal genitalia (XLAG) is a rare, genetic, central nervous system malformation disorder characterized, in males, by lissencephaly (with posterior predominance and moderately thickened cortex), complete absence of corpus callosum, neonatal-onset (mainly perinatal) intractable seizures, postnatal microcephaly, severe hypotonia, poor responsiveness and hypogonadism (micropenis, hypospadias, cryptorchidism, small scrotal sac). Defective temperature regulation and chronic diarrhea may be additionally observed. 